\title{
W GĄSZCZU FILOZOFICZNYCH ROZRÓŻNIEŃ PAWŁA ROJKA SYSTEMATYZACJA PODSTAWOWYCH ZAGADNIEŃ DOTYCZĄCYCH TROPÓW I UNIWERSALIÓW
}

Paweł Rojek, Tropy i uniwersalia. Badania ontologiczne, Warszawa: Wydawnictwo Naukowe Semper 2019, ss. 296, ISBN 978-83-7507-264-8

\begin{abstract}
In the MAZE of PhilosophiCAl Distinctions: PAWEe RoJEK's Systematization OF THE BASIC ISSUES CONCERNING TROPES AND UNIVERSALS

This paper reviews Pawel Rojek's book Tropy $i$ uniwersalia: Badania ontologiczne (Tropes and Universals: Ontological Investigations). The subject of the book are the titular notions of tropes (i.e., abstract particulars) and universals. The first three chapters contain conceptual clarifications and the remaining three chapters are devoted to the interpretation of particular philosophers (Roman Ingarden, Thomas Aquinas, Hegel, and George Frederick Stout) in the light of the previously introduced distinctions. The review summarizes each chapter and discusses some objections to the author's theses.

Keywords: Paweł Rojek, tropes, universals
\end{abstract}

\section{UWAGI OGÓLNE}

Przedmiotem książki Pawła Rojka Tropy i uniwersalia. Badania ontologiczne (2019) są tytułowe uniwersalia (definiowane jako jedności w wielości) oraz tropy (definiowane jako jednostkowe własności). Praca składa się z sześciu rozdziałów, z czego trzy pierwsze mają charakter systematyzujący i zawierają

* Instytut Filozofii, Uniwersytet Jagielloński, ul. Grodzka 52, 30-044 Kraków, joanna.luc. poczta@gmail.com, ORCID: https://orcid.org/oooo-00o3-2758-8230. 
analizy podstawowych pojęć i stanowisk, a kolejne trzy poświęcone są interpretacji dzieł Romana Ingardena, Tomasza z Akwinu oraz Hegla i George’a F. Stouta pod kątem problemu uniwersaliów i tropów.

Jak stwierdza Rojek w Zakończeniu, jego cel był głównie systematyzujący - chodziło o dookreślenie, na czym polegają filozoficzne debaty będące przedmiotem książki i odróżnienie ich od innych podobnych dyskusji, a nie o argumentowanie za określonym stanowiskiem. I rzeczywiście, książka Rojka z powodzeniem realizuje tak założony cel. Autor, wprowadzając kolejne rozróżnienia pojęciowe (niekiedy pochodzące od niego, a niekiedy istniejące już w literaturze filozoficznej) kreśli mapy możliwych stanowisk i umieszcza na nich znanych autorów. Orientację w tym gąszczu ułatwiają czytelnikowi liczne tabele i schematy.

Sądzę, że główną zaletą książki jest staranne rozróżnianie pojęć i zagadnień często niesłusznie utożsamianych. Można więc traktować ją jako zobrazowanie słów autora z Zakończenia:

Mimo upływu dwóch i pół tysiąca lat, filozofowie nadal spierają się na ten sam temat i komentują te same klasyczne teksty. Sądzę jednak, że to właśnie dyskusja o uniwersaliach może być ilustracją tego, na czym polega rozwój w filozofii. Tradycyjne stanowiska są bowiem coraz dokładniej formułowane, coraz lepiej widać związki między różnymi tezami, wciąż wreszcie pojawiają się - choć z rzadka - nowe pytania, nowe argumenty i nowe koncepcje (Rojek 2019: 262).

Na uwagę zasługuje szeroki zakres przytaczanej literatury. Jakkolwiek Rojka najtrafniej można umieścić w tradycji filozofii analitycznej, nie ogranicza się on do i tak zresztą bogatej literatury ontologicznej tego nurtu, lecz znajdujemy u niego odniesienia do Platona, Arystotelesa, scholastyki (przede wszystkim Tomasza z Akwinu), fenomenologii (Husserla i Ingardena) oraz Hegla. Tak szerokie spektrum odniesień nie burzy przy tym jednolitości książki, a wręcz przeciwnie - pokazuje pośrednio, że ci tak nieraz odlegli w czasie, przestrzeni i stylu myślenia filozofowie rozważali często te same problemy i dochodzili do przynajmniej częściowo podobnych wniosków.

Oprócz warstwy konceptualnej (odróżnienia pojęć i stanowisk) oraz erudycyjnej (ilustrowanie rozróżnień odniesieniami do literatury) w drugim rozdziale pojawia się warstwa formalna (autor przedstawia próbę formalizacji podstawowych dla pracy pojęć). Pozwala to jaśniej przedstawić relacje między nimi. 


\section{UWAGI NA TEMAT POSZCZEGÓLNYCH ROZDZIAŁÓW}

Przejdźmy do omówienia kolejnych rozdziałów, podkreślając z jednej strony to, co jest w nich szczególnie wartościowe, a z drugiej strony czyniąc pewne uwagi krytyczne dotyczące rozwiązań przyjętych przez autora.

2.1. WSTĘP

Wstęp służy przede wszystkim wprowadzeniu czytelnika w podstawową terminologię używaną w książce oraz ustaleniu polskich odpowiedników niektórych angielskich terminów. Decyzje te niekiedy są trudne i wymagają balansowania między zręcznością językową a adekwatnością. Jednym z ważnych i nieoczywistych rozróżnien, jakie się tu pojawiają, jest odróżnienie przeciwstawienia konkretne-abstrakcyjne od przeciwstawienia jednostkowe-ogólne:

To, co jednostkowe, jest niepowtarzalne, a to, co ogólne, może występować w wielu przypadkach. To, co abstrakcyjne, jest zależne ontologicznie, a to, co konkretne, do swojego istnienia nie wymaga żadnego innego bytu (2019: 10).

Z połączenia tych dwóch podziałów uzyskujemy cztery możliwe kategorie bytów: abstrakcyjne partykularia (tropy), konkretne partykularia, abstrakcyjne uniwersalia i konkretne uniwersalia. Jak wskazuje tytuł, przedmiotem książki są trzy spośród tych czterech kategorii; konkretne partykularia nie stają się osobnym przedmiotem rozważań, pojawiają się jedynie przy okazji analizy pozostałych kategorii.

Za autorem używam terminów „uniwersalia” i „powszechniki” synonimicznie. Należy też mieć na uwadze, że „partykularność” jest synonimem „jednostkowości”.

2.2. ROZDZIAE 1

W rozdziale 1, noszącym tytuł Problem uniwersaliów, autor odróżnia właściwy problem uniwersaliów (czy istnieją byty będące jednością w wielości, czyli powszechniki) od dwóch innych problemów często z nim niesłusznie utożsamianych: co jest odniesieniem wyrażeń ogólnych i czy istnieją byty idealne (rozumiane jako pozaczasowe i pozaprzestrzenne). Jest to o tyle istotne, o ile wiele ważnych postaci w historii filozofii tego rozróżnienia nie dokonywało, m.in. Platon, Russell, Quine, a na gruncie polskim Ajdukiewicz w znanym podręczniku Zagadnienia i kierunki filozofii.

Według Rojka dla zrozumienia właściwej problematyki uniwersaliów zasadnicze znaczenie ma zagadnienie jedności w wielości. Nie dostajemy wielu 
wyjaśnień, jak dokładnie należy rozumieć to wyrażenie $w$ ogólności (zapewne jest ono traktowane jako wystarczająco zrozumiałe samo przez się). Później w rozdziale 2 poznamy trzy sposoby dookreślania go, odpowiadające trzem rodzajom uniwersaliów. Uniwersalia nazywane są też „bytami ogólnymi”, co $\mathrm{z}$ uwagi na definicję ogólności znaczy właściwie to samo. Paradygmatycznym lub przynajmniej najczęstszym we współczesnej filozofii rodzajem jedności $\mathrm{w}$ wielości jest numerycznie tożsama własność występująca w kilku numerycznie różnych przedmiotach i przykład ten wystarcza do zbudowania odpowiednich intuicji na tym etapie rozważań, choć - jak się później okaże - nie jest to jedyny typ jedności w wielości. Większa część pierwszego rozdziału służy wykazaniu, że rzeczywiście problem uniwersaliów różni się od dwóch pozostałych kwestii.

Po pierwsze więc, nie należy utożsamiać uniwersaliów z odniesieniami wyrażeń ogólnych, przede wszystkim dlatego, że uniwersalia są czymś w świecie, a wyrażenia to twory językowe, pochodzące od człowieka. Mogą istnieć uniwersalia bez odpowiadających im predykatów, jak również mogą istnieć sensowne predykaty, którym nie odpowiadają żadne uniwersalia (na stronach 36-38 autor podaje przykłady). Konsekwencją tej możliwej rozbieżności między porządkami predykatów i uniwersaliów ma być nieskuteczność tzw. argumentu ze znaczenia za istnieniem uniwersaliów (nie można wyjaśnić prawdziwości zdań zawierających wyrażenia ogólne, nie zakładając istnienia uniwersaliów).

Sądzę, że w tym punkcie krytyka autora jest nieco zbyt surowa, ponieważ można oddzielić argument, zgodnie z którym sensowność zdań z wyrażeniami ogólnymi wymaga istnienia jakichś uniwersaliów, od argumentu, zgodnie z którym muszą to być uniwersalia stanowiące odniesienia tych konkretnych predykatów znajdujących się w owych zdaniach. Można zadać sobie pytanie, czy dałoby się dojść do tezy o istnieniu uniwersaliów (rozumianych jako jedności $\mathrm{w}$ wielości), całkowicie wykluczając z pola rozważań przesłanki językowe. Wymagałoby to poznawczego dostępu do jakichś niezależnych od języka przesłanek, na przykład biorących się z pewnego rodzaju intuicyjnego wglądu. Istnienie takich wglądów wolnych od elementów językowych jest jednak bardzo kontrowersyjną tezą epistemologiczną. Opieranie się w argumentacji za istnieniem uniwersaliów na tak wąskiej i kontrowersyjnej podstawie poznawczej niepotrzebnie osłabiałoby taką argumentację. Nawet więc jeśli obecność wyrażeń ogólnych w języku nie wystarcza do wyciągania wniosków o uniwersaliach, jest to wciąż jedna z najważniejszych (a być może nawet najważniejsza) przesłanka w rozważaniach na ich temat, szczególnie jeśli weźmiemy pod uwagę fakt, że ,język" obejmuje nie tylko język potoczny, lecz także języki, w których sformułowane są teorie naukowe, a więc jakikolwiek argument za uniwersaliami odwołujący się do nauki byłby również rodzajem argumentu z języka. 
Skoro odeszliśmy od idei jednoznacznej odpowiedniości między predykatami a uniwersaliami (czy szerzej: własnościami), można zadać pytanie, jakie są możliwe relacje tych dwóch porządków. Rojek podejmuje tę kwestię, podając jej oryginalną analizę. W tym celu rozróżnia trzy tezy. Predykaty prawdziwie stosujące się do przedmiotów: (P1) muszą oznaczać jaką́s własność, (P2) musi być to taka sama własność w każdym przypadku, ( $\left.\mathrm{P}_{3}\right)$ własność ta musi być universale. Zauważmy, że dopiero teza (P3) mówi coś o uniwersaliach, co jeszcze raz pokazuje przepaść między predykatami a uniwersaliami, której pokonanie wymaga kilku kroków. Możliwe relacje między porządkami predykatów i własności powstają z różnych kombinacji tych tez. W szczególności, ciekawe jest spostrzeżenie, że tezy (P2) i (P3) są niezależne, ponieważ predykat może się zawsze odnosić do uniwersaliów, ale nie zawsze do tych samych, albo że może odnosić się zawsze do takiej samej własności, lecz rozumianej nie jako universale.

Po drugie, nie należy utożsamiać uniwersaliów z bytami idealnymi. Zgodnie z niektórymi teoriami uniwersalia istnieją w czasie i przestrzeni ( $\mathrm{w}$ tych miejscach, gdzie znajdują się egzemplifikujące je rzeczy), a więc nie są idealne. $\mathrm{Z}$ kolei byty idealne mogą być jednostkowe - tak niekiedy myśli się o (przynajmniej niektórych) bytach matematycznych. Natomiast uniwersalia z definicji są ogólne. Rozróżnienie to ma ciekawą konsekwencję interpretacyjno-historyczną: otóż Platon, który często nazywany jest realistą skrajnym, ponieważ uznaje istnienie idei jako bytów niezależnych od rzeczy, w pewnym sensie $\mathrm{w}$ ogóle nie powinien być uznawany za realistę w kwestii uniwersaliów, ponieważ $\mathrm{w}$ jego teorii nie ma bytów, które są prawdziwymi jednościami $\mathrm{w}$ wielości, mimo że są w niej byty idealne. Rojek nazywa więc platonizm „ukrytym nominalizmem”, zapożyczając ten termin od Gustava Bergmanna.

Jest to świadomie kontrowersyjna i prowokacyjna interpretacja myśli Platona. Jej ocena wymaga rozważenia dwóch kwestii: po pierwsze, czy doktryna samego Platona została poprawnie zrekonstruowana, a po drugie, czy przy danej rekonstrukcji rzeczywiście należy orzec, że jest to teoria nominalistyczna. Pierwsza kwestia jest nazbyt złożona, by ją tutaj omawiać. Przyjrzyjmy się jednak nieco bliżej drugiemu problemowi. Rojek uważa Platona za nominalistę, dlatego że według Platona idee istnieją poza rzeczami, a nie w (wielu) rzeczach, a bycie jednością w wielości wymaga tego drugiego. Czy rzeczywiście jednak jest to jedyny sposób rozumienia jedności w wielości? Rojek sam podaje w kolejnym rozdziale trzy rozumienia tego pojęcia, z których tylko dwa pierwsze wiążą się z istnieniem czegoś jednego w wielu rzeczach. Trzeci rodzaj jedności w wielości dopuszczony przez niego polega na czymś innym (por. dalej). Jeśli zaakceptujemy takie dość liberalne podejście do pojęcia jedności w wielości, to można się zastanawiać, czy w teorii Platona relacja idei do rze- 
czy jednostkowych nie jest jakimś czwartym, nieoczywistym jej rodzajem. Idee niewątpliwie są w jakimś sensie czynnikiem jednoczącym względem rzeczy, niezależnie od tego, jak byłyby interpretowane. Jeżeli np. relacja rzeczy do idei polega na naśladownictwie tych drugich przez te pierwsze, to dzięki niej rzeczy upodabniają się do idei i pośrednio do siebie wzajemnie, co tworzy pewną jedność $\mathrm{w}$ wielości $\mathrm{w}$ szerszym sensie $-\mathrm{z}$ pewnością nie tak klarownym jak w przypadku powszechnika będącego tym samym czymś istniejącym $\mathrm{w}$ wielu rzeczach, lecz pytanie, czy mniej klarownym niż w przypadku trzeciego sensu powszechnika omówionego w rozdziale 2 (por. Piwowarczyk 2020).

\subsection{ROZDZIAE 2}

Rozdział 2, zatytułowany Trzy pojęcia uniwersaliów, ma na celu omówienie trzech typów powszechnika: abstrakcyjnych własności, nieokreślonych aspektów oraz konkretnych całości. Rojek stara się podać ich jednolitą analizę, opartą na dwóch relacjach: mereologicznej (część-całość) oraz niesamodzielności ontologicznej. Przyjrzyjmy się kolejno tym trzem typom powszechników.

We współczesnej filozofii analitycznej rozważa się przede wszystkim uniwersalia w pierwszym sensie, czyli abstrakcyjne własności rozumiane jako w pełni dookreślone (np. czerwień o dokładnie takim a takim odcieniu). Tego rodzaju universale jest jednym numerycznie bytem istniejącym $\mathrm{w}$ wielu numerycznie różnych przedmiotach. Relacja między własnością abstrakcyjną a przedmiotem, któremu przysługuje, jest nazywana inherencją. Inherencja ma dwa aspekty: mereologiczny (własność abstrakcyjna jest częścią przedmiotu - o tyle szczególną, że niemożliwą do oddzielenia) oraz niesamodzielności egzystencjalnej (istnienie własności abstrakcyjnej wymaga istnienia jakiejś rzeczy, której jest ona własnością - przy czym nie jest ważne, jaka dokładnie to rzecz będzie).

Drugi typ powszechnika to nieokreślone aspekty. Zdaniem autora takie rozumienie uniwersaliów dominowało w tradycji scholastycznej i fenomenologicznej, pod tym względem więc różnią się one od filozofii analitycznej. Relacja między własnością a aspektem jest nazywana determinacją; zatem własności inherują w rzeczach i determinują aspekty. Tej teorii ontologicznej często towarzyszyła równoległa teoria epistemologiczna: własności i aspekty poznawane są przez inne operacje umysłowe (rozróżniane m.in. przez Tomasza z Akwinu i Husserla): abstrakcję i indeterminację (ten drugi termin stanowi chyba autorską propozycję Rojka).

Na marginesie chciałabym zauważyć, że taka wizja poznania (najpierw poznaję rzecz, potem abstrahuję z niej własność, a na końcu dokonuję indeterminacji własności, uzyskując aspekt) zakłada, że poznanie intelektualne jedy- 
nie wydobywa to, co jest już w jakimś sensie obecne w poznaniu zmysłowym, co nie przystaje do hipotetyczno-dedukcyjnej koncepcji poznania naukowego, w której najpierw postuluje się pewne własności i relacje między nimi (w postaci teorii), a dopiero potem odnosi się tę teorię do przedmiotów. Jakkolwiek niektóre z tych własności mogą być zainspirowane doświadczeniem, to jednak wydaje się niemożliwe poznanie $\mathrm{w}$ drodze klasycznej abstrakcji np. spinu. Można zadać pytanie - wychodząc oczywiście poza zakres tematyczny recenzowanej książki - czy taka modyfikacja wizji poznania powinna jakoś wpłynąć na nasze rozumienie powszechników.

Determinacja, podobnie jak inherencja, jest rodzajem bycia częścią i rodzajem niesamodzielności. Różnica polega na tym, że determinacja wiąże się $\mathrm{z}$ niesamodzielnością jakościową, a nie tylko egzystencjalną. Na czym polega niesamodzielność jakościowa? Przynależność do tego, a nie innego przedmiotu nie zmienia w żaden sposób własności abstrakcyjnych, natomiast dookreślanie aspektu przez taką a nie inną własność zmienia go, ponieważ „to, co ogólne, jest w przedmiocie obecne nie jako nieokreślone, lecz właśnie jako określone" (Rojek 2019: 88).

Trzecim, najrzadziej omawianym i być może najtrudniejszym do zrozumienia rodzajem powszechnika są konkretne uniwersalia. W książce nazywane są także konkretnymi całościami, co jednak może być nieco mylące, ponieważ nie każda konkretna całość jest jednością w wielości, a więc konkretnym universale. Tak jak $\mathrm{w}$ dwóch poprzednich przypadkach, tak i tu konkretne universale jest charakteryzowane mereologicznie (choć tym razem to przedmioty są częściami universale, a nie na odwrót) i przez relację niesamodzielności (przedmiotów względem universale). Relacja między konkretnym powszechnikiem a podpadającymi pod niego przedmiotami zostaje nazwana tak samo jak w przypadku abstrakcyjnego universale - inherencją. Zmienia się jednak kierunek tej relacji (to przedmioty inherują $\mathrm{w}$ universale), a ona sama zostaje „poluzowana”. Zdaniem Rojka owo „poluzowanie” polega na słabszym rozumieniu niesamodzielności. Otóż niesamodzielność

może być stała albo tylko początkowa. W pierwszym wypadku istnienie przedmiotu wymaga stałego i równoczesnego istnienia jakiegoś innego przedmiotu, w tym drugim przedmiot wymaga istnienia innego przedmiotu tylko w momencie swojego powstawania, a potem może istnieć bez obecności początkowego warunku swojego zaistnienia (Rojek 2019: 104-105).

Taka analiza pojęcia konkretnego universale wydaje się dość zaskakująca i nie obejmuje wszystkich intuicji, które należy wiązać z tym pojęciem. Postulowana „więź” między przedmiotem a konkretnym universale jest zadziwiająco słaba. Wyobraźmy sobie, że pewien przedmiot $P$ w początkowym okresie swego istnienia jest częścią całości $C$ oraz jest zależny egzystencjalnie od $C$, a potem $P$ 
przestaje być zależny od $C$. Zgodnie z podaną definicją możemy orzec, że $C$ jest konkretnym universale, pod które podpada $P$. Czy gdy $P$ przestanie już być zależny od $C$, to coś go jeszcze łączy z $C$ ? Jeżeli $C$ dalej istnieje, to $P$ jest wciąż częścią $C$, ale jest to jedyna relacja, jaka pozostaje między $P$ a $C-$ jest to bardzo słaba „więź”, która nic istotnego nie mówi o tym, czym $P$ jest aktualnie. Czy rzeczywiście tak wygląda np. relacja człowieka do Człowieczeństwa, które jest podawane przez Rojka jako jeden z przykładów konkretnego universale? Czy rzeczywiście (jeśli już uznamy coś takiego jak konkretne universale Człowieczeństwo) jesteśmy skłonni myśleć o relacji człowieka do Człowieczeństwa w taki sposób, że od pewnego momentu („ustania” relacji zależności egzystencjalnej) jedynym powiązaniem człowieka z Człowieczeństwem jest relacja mereologiczna - ta sama, która łączy owego człowieka na przykład z sumą mereologiczną tegoż człowieka i przypadkowo napotkanego drzewa?

Istnieje również obawa, że znajdziemy przykłady podpadające pod tak skonstruowaną definicję, które niekoniecznie chcielibyśmy traktować jako przykłady konkretnych uniwersaliów. Powodem jest tu duża „liberalność” relacji mereologicznej. Rozważmy pewnego człowieka i jakikolwiek przedmiot, od którego był on początkowo zależny w swoim istnieniu (np. jakiś sprzęt medyczny podtrzymujący go przy życiu w ciągu pierwszych dni po urodzeniu). Oczywiście ów człowiek i ten przedmiot tworzą całość mereologiczną, ponieważ każda para przedmiotów taką całość tworzy. Raczej nie chcielibyśmy jednak powiedzieć, że taka całość jest konkretnym universale, mimo że podpada pod proponowaną przez Rojka definicję.

Problematyczne jest też nazywanie konkretnych całości uniwersaliami w sytuacji, gdy nalegamy, aby uniwersalia rozumieć jako jedności w wielości, ponieważ jakkolwiek konkretne universale jest czymś jednym, to nie jest ono „W wielości”, a raczej to wielość jest „w nim”. Odnosząc się do wspomnianej wcześniej tezy o nominalizmie Platona, można zapytać, czy relacja idei do rzeczy u Platona jest rzeczywiście mniej podobna do relacji abstrakcyjnych uniwersaliów do rzeczy niż relacja konkretnych uniwersaliów do rzeczy. Jeśli nie jest mniej podobna, to idee bardziej niż konkretne całości zasługują na miano uniwersaliów - przy założeniu, że abstrakcyjne uniwersalia są paradygmatycznym przypadkiem uniwersaliów i że podobieństwo do owego paradygmatycznego przypadku jest podstawą do nazwania uniwersaliami obiektów (czy też quasi-obiektów) innego typu.

W rozdziale 2 pojawiają się także próby formalnej analizy pojęć ontologicznych. Za pojęcia pierwotne Rojek proponuje uznać relacje inherencji i determinacji, po czym za ich pomocą definiuje m.in. abstrakcyjność, konkretność oraz różne typy powszechników. Oceniając te próby, należy mieć na uwadze, że autor nie ma na celu podania szczegółowej teorii analizowanych 
pojęć, lecz raczej ustalenie sposobu ich użycia, na który zgodziliby się zwolennicy wielu różnych teorii. Można zarzucić tej analizie na przykład to, że na oba pojęcia pierwotne nakłada się bardzo ogólne wymogi (i to w obu przypadkach te same), a mianowicie zwrotność, przechodniość i antysymetryczność. Istnieje wiele relacji spełniających te wymogi i interesujące byłoby znalezienie formalnych własności odróżniających inherencję i determinację od innych relacji częściowego porządku (a przede wszystkim jedną od drugiej). Być może jednak dodanie ich zawężałoby i konkretyzowało analizę bardziej, niż to było zamierzone, lub autor uważa, że to nie charakterystyki formalne wyróżniają inherencję i determinację spośród innych relacji częściowego porządku.

$$
\text { 2.4. ROZDZIAE } 3
$$

W rozdziale 3, pod tytułem Trzy teorie tropów, Rojek klasyfikuje teorie tropów $-\mathrm{z}$ jednej strony według różnych możliwych rozumień samej tej kategorii, a z drugiej strony według różnych możliwości łączenia jej z innymi kategoriami ontologicznymi. Ogólna charakterystyka kategorii tropów jest następująca:

Kluczowe dla pojęcia tropu są więc dwa określenia: abstrakcyjność i partykularność. Abstrakcyjność polega na byciu niesamodzielną częścią czegoś. [...] Partykularność tropów polega na tym, że mogą one przysługiwać tylko jednemu przedmiotowi w jednym czasie. Często wyraża się to w ten sposób, że abstrakcyjne partykularia mogą istnieć tylko w jednym miejscu w czasie i przestrzeni (2019: 110).

Trzecie zdanie jest trochę niejasne: nie wiadomo, czy przez „miejsce” należy rozumieć punkt, czy też rozciągły obszar przestrzeni lub czasoprzestrzeni (przypuszczam, że wszystkie te możliwości powinny być dopuszczalne). Ponadto owo ,jedno miejsce w czasie” sugeruje, że tropy istnieją momentalnie i w związku z tym nie mogą być czasowo rozciągłe, co wydaje się dość mocnym ograniczeniem na etapie formułowania wyjściowej definicji pojęcia tropu. Z pewnością da się pomyśleć koncepcję tropów, zgodnie z którą danej rzeczy może przysługiwać jednostkowa własność przez pewien okres dłuższy niż punktowy moment czasu. Nawet jeśli ostatecznie należałoby tę koncepcję odrzucić, to nie wydaje się ona analitycznie fałszywa, tzn. nie widać, aby była wykluczona przez samą treść pojęcia własności jednostkowej. Być może jednak Rojkowi chodziło tylko o to, że w danej chwili dany trop przysługuje nie więcej niż jednemu przedmiotowi, co nie oznacza, że nie może on istnieć w innych chwilach - tekst wydaje się dopuszczać oba odczytania wyrażenia „w jednym czasie”. Przy tym drugim odczytaniu, zapewne rozsądniejszym, można się zastanawiać, co dzieje się w przypadku, gdy jeden przedmiot jest częścią innego. Czy przedmiotowi może przysługiwać własność jednostkowa, 
która jest zarazem własnością jednostkową innego przedmiotu będącego jego częścią? Jeśli tak, to ściśle biorąc, nie jest prawdą, że w danej chwili trop przysługuje nie więcej niż jednemu przedmiotowi. Prawdą byłaby nieco słabsza teza, że jeśli w danej chwili trop przysługuje pewnemu przedmiotowi, to istnieje taki przedmiot, że wszystkie przedmioty, którym ów trop przysługuje, są jego częściami (właściwymi lub niewłaściwymi).

Do tej wyjściowej charakterystyki można dodawać dalsze określenia. Tropy można traktować bądź jako „przechodnie” (tzn. takie, że choć istnieją one w danym przedmiocie, mogtyby istnieć w innym; przynależność do tego akurat przedmiotu nie jest częścią ich tożsamości) bądź jako „nieprzechodnie” (przynależność do tego, a nie innego przedmiotu jest częścią ich tożsamości). Do tego dochodzi rozróżnienie na tropy proste i złożone (np. z nieokreślonych aspektów), co daje w sumie cztery pojęcia tropów.

Jakkolwiek tropy są często podstawą budowy ontologii jednokategorialnej (tj. rekonstruującej inne kategorie ontologiczne z tropów), to wcale nie musi być to jedyne ich zastosowanie i można z powodzeniem tworzyć ontologie łączące tropy z innymi kategoriami, w szczególności z kategoriami uniwersaliów i/lub substancji. Według Rojka tak właśnie uczynili Ingarden, Tomasz z Akwinu, a także Stout (i być może Hegel), co zostało szczegółowo pokazane w rozdziałach 4-6. Tomasz z Akwinu lączył tropy z aspektami, Stout i Hegel z konkretnymi uniwersaliami, a u Ingardena występują one obok m.in. przedmiotów, idei i czystych jakości idealnych. Sądzę, że zastosowanie wprowadzonych pojęć do interpretacji tak różnych pod wieloma względami autorów pokazuje ich nośność i użyteczność, a także pozwala uzyskać nowe i świeże spojrzenie na poglądy wymienionych filozofów.

2.5. ROZDZIAE 4

Przedmiotem rozdziału 4 (Teoria tropów Romana Ingardena) jest przedstawienie $\mathrm{i}$ interpretacja istotnych $\mathrm{z}$ punktu widzenia tematu książki tez ontologii Ingardena. Ingarden przyjmował w swojej ontologii oprócz jednostkowych przedmiotów realnych także m.in. przedmioty intencjonalne, jednostkowe własności (czyli tropy, choć oczywiście nie używał tej nazwy), czyste jakości idealne i idee. Jako że idee i czyste jakości idealne nie istnieją w przedmiotach, a własności przedmiotów nie są ogólne, to Ingardena można uznać za ukrytego nominalistę z tego samego powodu co Platona. Rojek traktuje to jako słabość teorii Ingardena, ponieważ zarazem wprowadza ona bogatą ontologię i nie rozwiązuje podstawowego problemu jedności w wielości. Pewnego usprawiedliwienia doszukuje się $\mathrm{w}$ fakcie, że to nie ten problem był głównym przedmiotem zainteresowania Ingardena, ponieważ idee wprowa- 
dził on w celu rozwiązania problemu współwystępowania własności w przedmiocie (i momentów własności we własnościach). Ingarden zauważa bowiem, że pewne własności (czy momenty własności) w sposób konieczny ze sobą współwystępują, a pewne inne w sposób konieczny się wykluczają i to ta obserwacja, a nie spór o uniwersalia, stanowi motywację dla jego rozważań. Idee są czymś w rodzaju idealnych odpowiedników rzeczy i własności (o różnym poziomie określoności), które kodują owe związki koniecznościowe.

Zdaniem Rojka brak właściwego podjęcia sporu o uniwersalia sprawia jednak, że Ingardenowi nie udaje się rozwiązać także problemu współwystępowania: jeśli idee są zewnętrzne wobec rzeczy, to ich związek z nimi jest zbyt słaby, aby były w stanie ugruntować konieczności w rzeczach. Mimo tak surowej oceny (pojawia się wręcz stwierdzenie o fiasku teorii uniwersaliów Ingardena) Rojek docenia niektóre elementy tego systemu. W szczególności podaje koncepcję łączenia momentów własności we własność jako inspirację dla własnej koncepcji niesamodzielności jakościowej w rozdziale 2.

W swojej krytyce zarówno Platona, jak i Ingardena, Rojek zakłada, że idealność nie tylko nie pociąga bycia powszechnikiem, lecz wręcz się z nim wyklucza, ponieważ byty idealne nie występują w wielu przypadkach - są jednościami, ale nie w wielości (por. Piwowarczyk 2020). Jest to zgodne z intuicjami Ingardena, dla którego było niedopuszczalne, aby idee i czyste jakości idealne istniały $\mathrm{w}$ przedmiotach, ponieważ ich sposób istnienia (idealny) różni się od sposobu istnienia przedmiotów (realny). To stanowiło podstawę jego poglądu o zewnętrzności idei względem przedmiotów. Gdyby jednak odrzucić to założenie i dopuścić powiązanie jednego bytu z kilkoma sposobami istnienia, można by stworzyć teorię, zgodnie z którą uniwersalia $\mathrm{z}$ jednej strony istnieją $\mathrm{w}$ przedmiotach, a $\mathrm{z}$ drugiej strony istnieją też samodzielnie poza przedmiotami i są numerycznie identyczne w każdej z tych realizacji. Taka teoria zapewne byłaby zdaniem Rojka nadmiarowa, ale przynajmniej wydaje się spójna. Jeżeli rzeczywiście uznamy ją za spójną, to założenie autora, że bycie powszechnikiem i idealność z zasady się wykluczają, okazuje się zbyt daleko idące.

2.6. ROZDZIAE 5

Rozdzial 5 (Teoria tropów św. Tomasza z Akwinu) zawiera interpretację teorii własności Tomasza z Akwinu. Zdaniem Rojka można temu filozofowi przypisać połączenie realizmu w kwestii uniwersaliów (choć obejmującego tylko aspekty) z teorią tropów. Akwinata przyznaje istnienie tylko temu, co indywidualne i w pełni określone (zarówno przedmiotom, jak i własnościom). Nie jest to jednak równoznaczne $\mathrm{z}$ odrzuceniem uniwersaliów, ponieważ 
„powszechniki istnieją $\mathrm{w}$ rzeczach $\mathrm{w}$ sposób potencjalny $i$ naturalny, a w umysłach w sposób aktualny i intencjonalny" (2019: 205). Nie jest jasne, co autor rozumie przez istnienie „naturalne” (czy jest to np. odpowiednik istnienia realnego u Ingardena?), ale ważniejsze chyba jest to pierwsze określenie, tj. potencjalność istnienia powszechników. Również w odniesieniu do potencjalności można jednak mieć wątpliwości terminologiczne: własności indywidualne istnieją albo $\mathrm{w}$ rzeczach, albo w umyśle je poznającym, nigdy „same”, a więc w tym sensie one również są tylko potencjalne, a jednak Tomasz z Akwinu przyznaje im radykalnie inny status niż własnościom ogólnym. Być może, tak jak wcześniej, problem da się rozwiązać przez rozróżnienie niesamodzielności egzystencjalnej i jakościowej, co zresztą Rojek sam sugeruje (2019: 180). Wówczas istnienie potencjalne aspektów sprowadzałoby się do ich niesamodzielności jakościowej względem tropów. Można jednak wtedy zapytać, dlaczego niesamodzielność jakościową należy wiązać z istnieniem potencjalnym, a niesamodzielności egzystencjalnej nie należy.

\subsection{ROZDZIAE 6}

W ostatnim rozdziale noszącym tytuł Heglowska teoria tropów Rojek podejmuje się trudnego przedsięwzięcia interpretacji tekstów Hegla. Trzy etapy Heglowskiego schematu dochodzenia do prawdy wiążą się z trzema rodzajami powszechników. Najpierw mamy więc poznanie zdroworozsądkowe, skupiające się na tym, co konkretne i bezpośrednie; poznajemy wtedy powszechnik empiryczny, który zbiera razem momenty jednostkowe na podstawie ich porównania, nie dostrzegając jednak w nich czegoś prawdziwie wspólnego (można go interpretować jako zbiór tropów). Kolejny etap to refleksja rozsądku, dochodząca do abstrakcyjnego powszechnika, który jest już ogólny (można go więc utożsamić z aspektem). Hegel zarzuca temu powszechnikowi pewnego rodzaju ubóstwo, nazywa go „bezbarwnym i beztreściowym”, „pozbawionym życia i ducha" itp. W trzeciej fazie następuje rodzaj dialektycznej syntezy obu poprzednich faz, w wyniku której poznajemy konkretny powszechnik uchwytujący i wielość, i jedność, będący zarazem ogólny, ale już bez utraty bogactwa szczegółowości. Jest on w pewnym sensie nadrzędny względem indywiduów pod niego podpadających: indywidua zawierają się w nim i od niego zależą. Rojek argumentuje, że przyjęcie, iż Heglowi chodziło o konkretne powszechniki w tym sensie, pozwala wyjaśnić więcej jego tez niż alternatywne interpretacje. Nie podaje jednak dokładniejszej analizy, na czym polega zależność przedmiotów od konkretnego powszechnika, a więc zapewne w domyśle jest ona rozumiana tak jak w rozdziale 2. 
Druga część rozdziału 6 poświęcona jest interpretacji pism Stouta, pioniera współczesnej teorii tropów. Zdaniem Rojka, jakkolwiek Stout wypierał się związków z heglizmem, przedstawiona przez niego koncepcja relacji uniwersaliów do tropów (zwanej jednością dystrybutywną) przypomina relację konkretnych uniwersaliów do podpadających pod nie przedmiotów. Jeśli jest to interpretacja trafna, znaczyłoby to, że istniało interesujące i nietrywialne powiązanie historyczne między teorią tropów a heglizmem. Późniejsi przedstawiciele tej teorii zamienili jednak jedność dystrybutywną na podobieństwo, tym samym zrywając tę więź, jeżeli rzeczywiście ona istniała.

\section{PODSUMOWANIE}

Książka Pawła Rojka jest niewątpliwie wartościowym i twórczym wkładem w systematyzację zagadnień ontologicznych dotyczących uniwersaliów i tropów. Autor zbiera w jednym miejscu rozsiane w literaturze i wciąż często przeoczane rozróżnienia, jak również dodaje do nich własne. Jego interpretacje innych filozofów są dobrze poparte tekstami źródłowymi, choć też czasem świadomie kontrowersyjne. Można tę książkę czytać zarówno jako wprowadzenie do pewnej części tematyki ontologicznej (z racji jej systematycznego charakteru), jak również jako specjalistyczną monografię (z racji jej oryginalnych elementów).

\section{BIBLIOGRAFIA}

Piwowarczyk M. (2020), Platonizm a spór o uniwersalia. W związku z książkq Pawła Rojka Tropy i uniwersalia, „Filozofia Nauki” 28(2) [110], 113-133.

Rojek P. (2019), Tropy i uniwersalia. Badania ontologiczne, Warszawa: Wydawnictwo Naukowe Semper. 